\title{
Myxoid Stroma Formation
}

National Cancer Institute

\section{Source}

National Cancer Institute. Myxoid Stroma Formation. NCI Thesaurus. Code C35998.

A morphologic finding that indicates the presence of myxoid changes in the stroma of a tissue sample. 